\title{
Apoptosis-promoted tumorigenesis: $\gamma$-irradiation- induced thymic lymphomagenesis requires Puma-driven leukocyte death
}

Ewa M. Michalak, ${ }^{1,2,4}$ Cassandra J. Vandenberg, ${ }^{1}$ Alex R.D. Delbridge, ${ }^{1,2} \mathrm{Li} \mathrm{Wu}^{1,2}$ Clare L. Scott, ${ }^{1,2}$ Jerry M. Adams, ${ }^{1,2,3}$ and Andreas Strasser $1,2,3,5$

${ }^{1}$ The Walter and Eliza Hall Institute of Medical Research, Parkville VIC 3050, Australia; ${ }^{2}$ Department of Medical Biology, The University of Melbourne, Parkville VIC 3010, Australia

\begin{abstract}
Although tumor development requires impaired apoptosis, we describe a novel paradigm of apoptosis-dependent tumorigenesis. Because DNA damage triggers apoptosis through p53-mediated induction of $\mathrm{BH} 3-0 n l y$ proteins Puma and Noxa, we explored their roles in $\gamma$-radiationinduced thymic lymphomagenesis. Surprisingly, whereas Noxa loss accelerated it, Puma loss ablated tumorigenesis. Tumor suppression by Puma deficiency reflected its protection of leukocytes from $\gamma$-irradiation-induced death, because their glucocorticoid-mediated decimation in Puma-deficient mice activated cycling of stem/ progenitor cells and restored thymic lymphomagenesis. Our demonstration that cycles of cell attrition and repopulation by stem/progenitor cells can drive tumorigenesis has parallels in human cancers, such as therapy-induced malignancies.
\end{abstract}

Supplemental material is available at http://www.genesdev.org. Received April 22, 2010; revised version accepted June 14, 2010.

It is now widely accepted that one hallmark of cancer is abatement of apoptosis (Hanahan and Weinberg 2000), commonly through inactivation of the p53 tumor suppressor (Vousden and Lu 2002), but sometimes through loss of a proapoptotic BH3-only protein of the Bcl-2 family, such as Puma, or overexpression of one of their prosurvival relatives (Adams and Cory 2007). Exposure of mice to four weekly doses of 1.5-Gy $\gamma$-irradiation elicits thymic lymphoma due to oncogenic mutations resulting from DNA double-strand breaks (for review, see Kaplan 1964). The transformation target (cell in which transformation begins) for these tumors is a primitive hematopoietic stem/progenitor cell in the bone marrow, because shielding both femora or transplanting undamaged hema-

[Keywords: Apoptosis; DNA damage; p53; Puma; Noxa; tumor suppressor] ${ }^{3}$ These authors contributed equally to this work.

${ }^{4}$ Present address: Department of Molecular Biology, The Netherlands Cancer Institute, Amsterdam 1066 CX, The Netherlands.

${ }^{5}$ Corresponding author.

E-MAIL strasser@wehi.edu.au; FAX 61-3-9347-0852.

Article is online at http://www.genesdev.org/cgi/doi/10.1101/gad.1940110. topoietic stem/progenitor cells ablates the tumorigenesis (Kaplan 1964).

The thymic lymphomagenesis induced by $\gamma$-irradiation is markedly enhanced by deficiency in p53 (Kemp et al. 1994), which controls DNA damage-induced cell cycle arrest, DNA repair, and apoptosis (Vousden and Lu 2002). The proapoptotic activity of p53 relies on Puma and, to a lesser extent, Noxa-the BH3-only Bcl-2 family members that it can transcriptionally activate (Oda et al. 2000; Nakano and Vousden 2001; Yu et al. 2001; Villunger et al. 2003). Links between deficiencies in BH3-only proteins and human cancer are accumulating (Tagawa et al. 2005; Adams and Cory 2007), and loss of Puma, Bim, or, in certain contexts, Noxa accelerates c-Myc-induced lymphomagenesis in mice (Egle et al. 2004b; Hemann et al. 2004; Garrison et al. 2008; Michalak et al. 2009). To investigate how p53-mediated apoptosis restrains $\gamma$-irradiationinduced thymic lymphoma development, we examined the consequences of Noxa and/or Puma loss by gene disruption.

\section{Results and Discussion}

Noxa loss enhances $\gamma$-radiation-induced thymic lymphoma development

Notably, after fractionated $\gamma$-irradiation, nox $a^{-1-}$ mice developed thymic lymphoma with markedly higher incidence and accelerated rate compared with wild-type mice (median survival: $126 \mathrm{~d}$ for noxa ${ }^{-/-}$vs. $217 \mathrm{~d}$ for wild type; $P<0.0005$ ) (Fig. 1A). There was even a trend toward accelerated lymphomagenesis in nox $a^{+/-}$mice (median survival, $162 \mathrm{~d}$ ), but this did not reach significance $(P=0.064)$. The lymphoma immunophenotypes (Supplemental Fig. 1A-C) in noxa $a^{+/-}$, noxa $a^{-/-}$, and $p 53^{+/-}$ mice were comparable $(P<0.3)$ (Fig. 1A), although the lymphomas from $p 53^{+-}$mice were somewhat larger (Supplemental Fig. 1D). The tumorigenesis in nox $a^{+/-}$ mice did not require loss of heterozygosity, because allele-specific PCR revealed that nine unselected nox $a^{+/-}$ thymic lymphomas all retained the wild-type noxa allele (Supplemental Fig. 1E). Furthermore, high levels of p19Arf, indicative of loss of p53 pathway function, were apparent in all (six out of six) $p 53^{+/-}$tumors, as reported (Kemp et al. 1994), but in only three out of 10 wild-type, one out of eight noxa $a^{+--}$, and one out of eight noxa $a^{-/-}$ lymphomas tested (wild type vs. $p 53^{+/-}, P<0.01 ;$ noxa $a^{-1-}$ vs. $p 53^{+/-}, P<0.005$; wild type vs. nox $\left.a^{-1-}, P=0.6\right)$ (Fig. 1B). Thus, in this model, tumor suppression by p53 relies in part on its direct transcriptional target, Noxa.

\section{Noxa loss enhances survival of primitive hematopoietic stem/progenitor cells, but not their more differentiated progeny}

As expected, $\gamma$-irradiated Noxa-deficient and wild-type thymocytes exhibited comparable DNA damage, as demonstrated by $\gamma \mathrm{H} 2 \mathrm{AX}$ induction (Supplemental Fig. 2). Noxa deficiency did not protect most leukocyte populations: After $\gamma$-irradiation on days 0 and 7 , total bone marrow leukocytes and thymocytes (Fig. 1C), including the four major thymic lymphocyte subpopulations (Supplemental Fig. 3), all dropped and rebounded comparably 
A

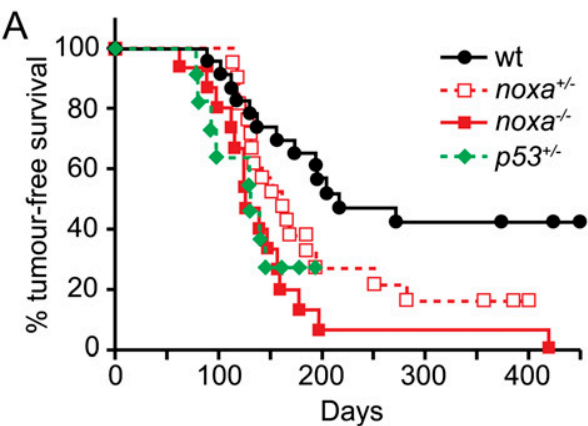

C

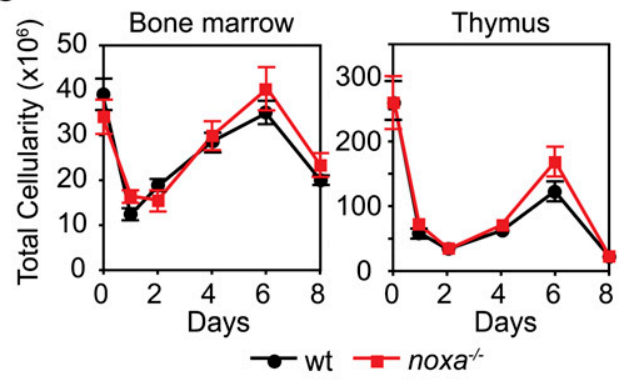

B

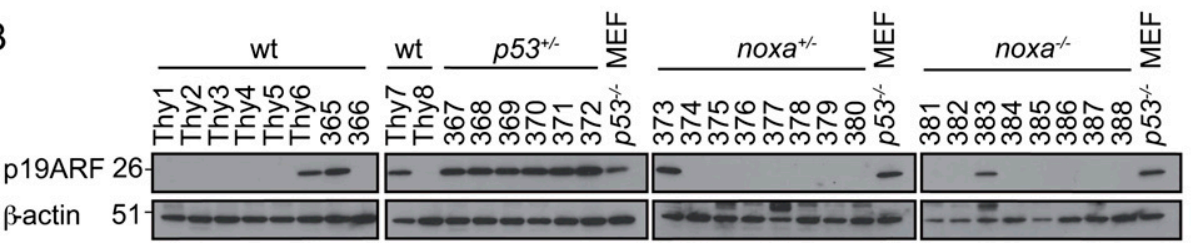

Figure 1. Noxa deficiency enhances $\gamma$-irradiation-induced thymic lymphoma development. (A) Kaplan-Meier curves showing percentage survival of tumor-free mice of the indicated genotypes exposed to four weekly doses of $\gamma$-irradiation (1.5 Gy). Thymic lymphomas arose with higher incidence and significantly $(P<0.0005)$ earlier in nox $a^{-1-}$ mice $(n=16)$ than wild-type mice $(n=23)$. Differences in tumor onset between wild-type and nox $a^{+/-}$mice $(n=21)$, and between noxa $a^{-1-}$ and $p 53^{+/-}$mice $(n=11)$ were not significant $(P=0.064$ and $P=0.76$, respectively). $(B)$ Western blot analysis of p19Arf and $\beta$-actin (loading control) in unselected thymic lymphomas of the indicated genotypes. $p 53^{+/-}$thymic

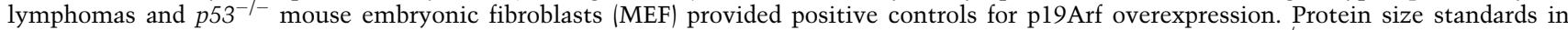
kilodaltons are indicated. $(C)$ Total leukocyte cellularity of the bone marrow and thymus from wild-type and nox $a^{-/-}$mice that had received 1.5 Gy $\gamma$-irradiation on days 0 and 7. Mean \pm SEM, $n=3-7$ for each genotype and day of analysis.

in $\operatorname{nox}^{-/-}$and wild-type mice. Furthermore, in tissue culture, Noxa-deficient early thymic progenitors (ETPs; $\mathrm{CD} 4{ }^{\mathrm{lo}} \mathrm{CD} 3^{-} \mathrm{CD} 8{ }^{-} \mathrm{cKit}^{\text {hi }}$ ) (data not shown) and bone marrow-derived common lymphoid progenitors /CLPs;
Lin ${ }^{-}$Sca- $1^{+}$c-kit ${ }^{\text {int }} \mathrm{IL}-7 \mathrm{R}^{+}$) were normally sensitive to $\gamma$-irradiation and spontaneous death (Fig. 2A), as are the major noxa $a^{-1-}$ thymocyte subpopulations $\left(\mathrm{CD}^{+} 8^{+}\right.$, $\mathrm{CD}^{+} 8^{-}$, and $\left.\mathrm{CD}^{-} 8^{+}\right)$(Villunger et al. 2003).
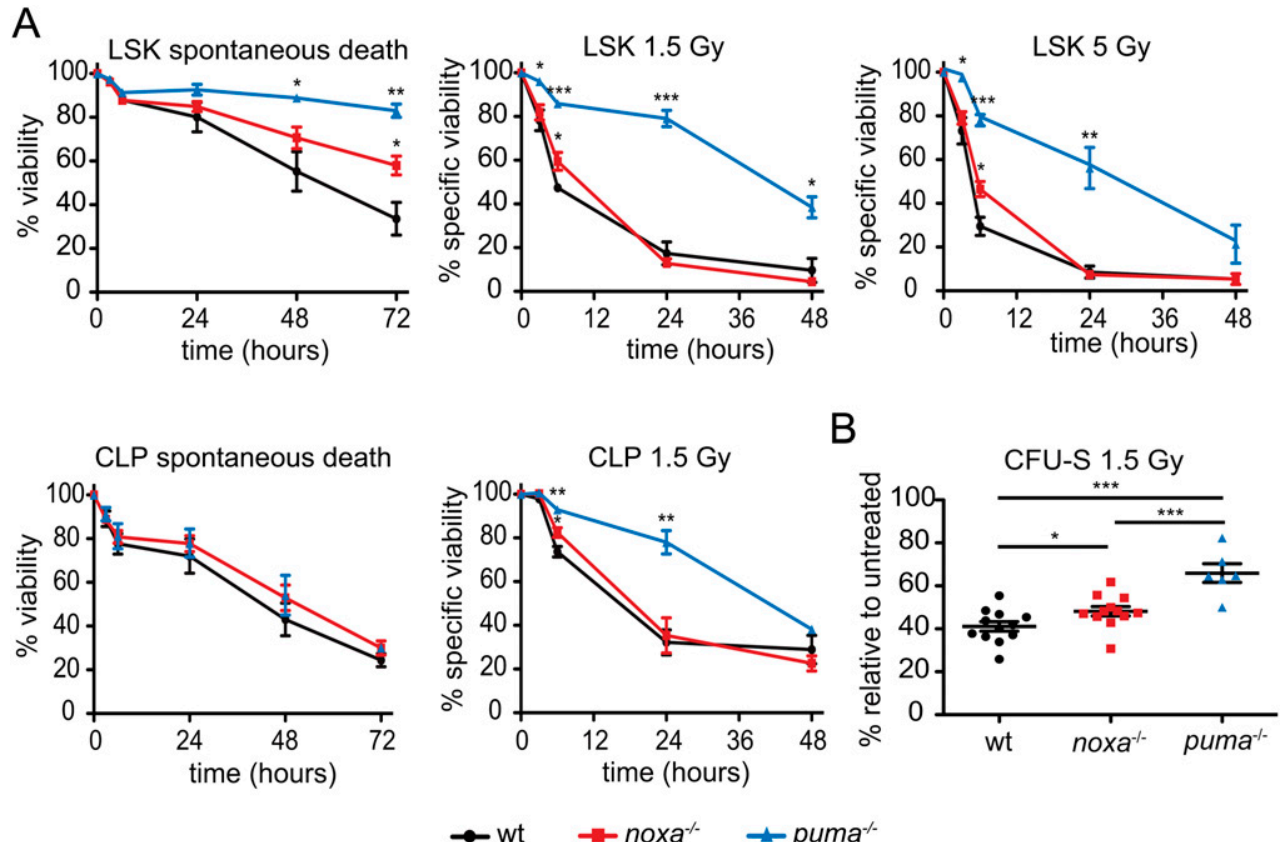

Figure 2. Sensitivity of leukocyte populations from Noxa- or Puma-deficient mice to $\gamma$-irradiation-induced or spontaneous apoptosis. $(A)$ Sensitivity in vitro of the indicated bone marrow cell subsets to $\gamma$-irradiation or spontaneous death (no cytokine support). LSK stem/progenitor cells and CLPs isolated from the marrow of wild-type, noxa $a^{-/-}$, and $p u m a^{-/-}$mice were left untreated or were $\gamma$-irradiated $(1.5$ or $5 \mathrm{~Gy})$, and were then cultured in vitro, and viability was assessed by Annexin V/PI staining and FACS analysis. Mean \pm SEM, $n=3-4 .\left({ }^{\star}\right) P<0.05$; $\left({ }^{\star \star}\right) P<0.01$; $\left(^{\star \star \star}\right) P<0.001 .(B)$ Bone marrow cells from wild-type, noxa $a^{-1-}$, and $p u m a^{-/-}$mice were $\gamma$-irradiated (1.5 Gy) and transplanted into $\gamma$-irradiated wild-type recipients, and macroscopic spleen colonies (CFU-S) were counted $12 \mathrm{~d}$ later. Mean $\pm \mathrm{SEM}, n=6-12$ donor mice. $\left({ }^{\star}\right) P<0.05$; $\left(^{\star \star}\right) P<$ $\left.0.01 ;{ }^{\star \star \star}\right) P<0.001$. CFU-S numbers from untreated marrow cells of these genotypes were comparable (Supplemental Fig. 5D). 
In line with evidence that the thymic lymphomas arise from mutated primitive bone marrow cells (Kaplan 1964), noxa mRNA was induced in hematopoietic stem/ progenitor cells $\left(\mathrm{Lin}^{-} \mathrm{Sca}-1^{\mathrm{hi}} \mathrm{c}-\mathrm{Kit}^{\mathrm{hi}} \mathrm{IL}-7 \mathrm{R}^{-}\right.$[LSK]) in a p53-dependent manner in response to DNA damage (Supplemental Fig. 4). Interestingly, Noxa loss afforded the LSK cells, including those that produce colonies in spleens of lethally irradiated mice (day 12 colony-forming unit-spleen [CFU-S]), with significant $(P<0.05)$, albeit modest, protection against $\gamma$-irradiation and cytokine deprivation (Fig. 2A,B). Thus, Noxa loss probably promotes thymic lymphomagenesis by enhancing survival of the rare bone marrow-resident stem/progenitor cells that have sustained oncogenic mutations, which evoke stress that activates p53 (see below; Hanahan and Weinberg 2000; Vousden and Lu 2002). However, since the lymphomas arise faster in $p 53^{-l-}$ than noxa $a^{-1-}$ mice (Kemp et al. 1994), Noxa loss only partially substitutes for p53 deficiency, probably because p53 loss obliterates not only DNA damage-induced apoptosis, but also multiple other pathways, including coordination of DNA repair (Vousden and Lu 2002).

\section{Puma loss prevents $\gamma$-radiation-induced thymic lymphoma development}

In response to DNA damage, p53 also induced puma mRNA in the LSK cells (Supplemental Fig. 4), and Puma deficiency protected these stem/progenitor cells, including those capable of forming CFU-S, against $\gamma$-radiationinduced apoptosis much more potently than did Noxa loss (Fig. 2A,B; Supplemental Fig. 5). Remarkably, however, thymic lymphoma development was ablated by the absence of Puma (zero out of 18 mice, $P<0.0002$ compared with wild type), and was greatly impaired by the loss of even a single puma allele (one out of $15, P<$ 0.0025 , compared with wild type) (Fig. 3A). Moreover, mice lacking both Noxa and Puma, or those bearing a vav-bcl-2 transgene, in which all hematopoietic cells (but not other cell types) are profoundly resistant to DNA damage-induced apoptosis (Ogilvy et al. 1999; Erlacher et al. 2005; Michalak et al. 2008), were also highly refractory to the thymic lymphoma development (Fig. 3A). Thus, counterintuitively, apoptosis of leukocytes provides an essential contribution to $\gamma$-radiation-induced thymic lymphomagenesis. Although p53 loss, like Puma deficiency, prevents DNA damage-induced apoptosis in hematopoietic cells (Clarke et al. 1993; Lowe et al. 1993), $\gamma$-irradiated $p 53^{-1-}$ mice (Kemp et al. 1994), and even p53 ${ }^{-1-}$ puma $^{-1-}$ mice (Labi et al. 2010), still develop thymic lymphoma. We attribute this to the fact that Puma loss prevents only DNA damage-induced, p53mediated apoptosis (Jeffers et al. 2003; Villunger et al. 2003), whereas p53 deficiency obliterates multiple additional processes, including cellular senescence and coordination of DNA repair, which constitute critical tumor-suppressive mechanisms, particularly in lymphocytes (Vousden and Lu 2002).

\section{Leukocyte depletion by dexamethasone restores $\gamma$-radiation-induced thymic lymphoma development in Puma-deficient mice}

Notably, unlike Noxa deficiency (Fig. 1C), Puma loss (even loss of one puma allele) (data not shown) greatly
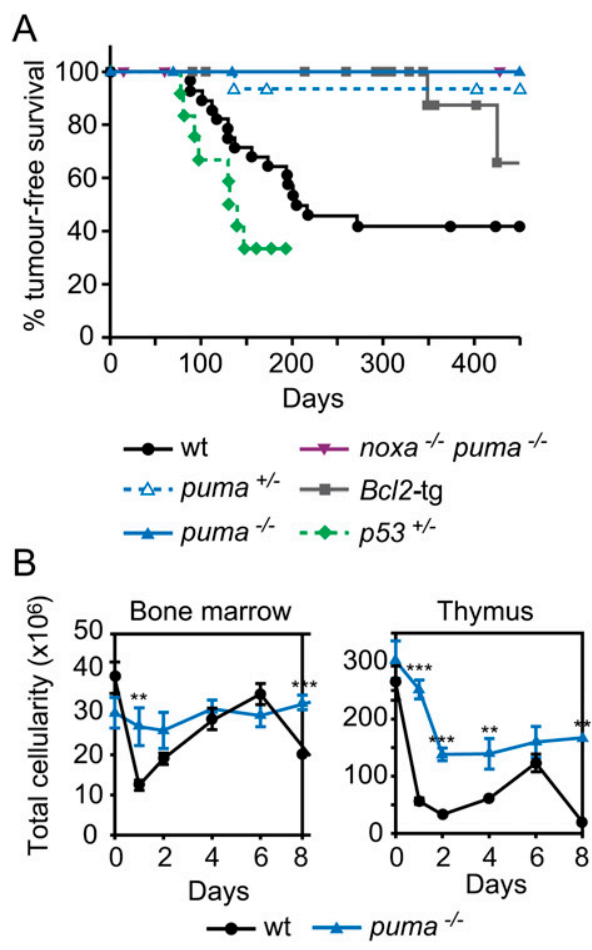

Figure 3. Loss of Puma prevents $\gamma$-irradiation-induced thymic lymphoma development. (A) Kaplan-Meier curves showing percentage tumor-free survival of mice exposed to four weekly doses of $\gamma$-irradiation $(1.5 \mathrm{~Gy})$. Only one out of $15 \mathrm{puma}^{+/-}$mice developed a thymic lymphoma $\left(\mathrm{CD}^{+} 8^{+}\right)$after $137 \mathrm{~d}$; regenotyping confirmed puma heterozygosity in this animal. Only one out of $19 \mathrm{vav}-b c l-2$ transgenic mice developed a thymic lymphoma (after 349 d); all other deaths reflected systemic lupus erythematosus (SLE)-like autoimmune disease or follicular B-cell lymphoma-diseases common in these animals (Egle et al. 2004a). No thymic lymphomas arose in puma $a^{-1-}(n=18)$ or noxa $a^{-1-}$ puma $^{-1-}(n=16)$ mice. Thymic lymphomas arose faster in $p 53^{+/-}$mice $(n=11)$ than wild-type mice $(n=28 ; P<0.02)$ and faster in wild-type mice than all other genotypes shown $(P<0.004)$. $(B)$ Total leukocyte cellularity of the bone marrow and thymus from wild-type and puma $^{--}$mice following $\gamma$-irradiation $(1.5 \mathrm{~Gy})$ on days 0 and 7. Mean $\pm \operatorname{SEM}, n=$ 2-5. $\left.\left(^{\star \star}\right) P<0.01 ;{ }^{\star \star \star}\right) P<0.001$. Data on bone marrow and thymus cellularity for wild-type mice are the same as those shown in Figure $1 \mathrm{C}$-as wild-type, noxa $a^{-1-}$, and $\mathrm{puma}^{-1-}$ mice were studied in parallel-but the data from nox $a^{-1-}$ and puma $^{-/-}$mice are presented in two separate figures ( $B$ and Fig. 1C) and are described in separate parts of the text for the sake of clarity.

reduced the attrition of bone marrow leukocytes and thymocytes in the $\gamma$-irradiated mice (Fig. 3B), as might be expected given the ability of Puma but not Noxa to target all Bcl-2 prosurvival proteins (Adams and Cory 2007). Conceivably, the attrition of thymocytes and/or marrow leukocytes might promote lymphomagenesis, because their normal phagocytic clearance is overwhelmed and secondary necrosis elicits inflammation, which can promote tumorigenesis in certain settings (Mantovani et al. 2008). However, loss of the essential Toll-like receptor signal transducer Myd88, which is required for necrosis-induced inflammatory cytokine production and consequent tumorigenesis in carcinogentreated mice (Naugler et al. 2007; Rakoff-Nahoum and Medzhitov 2007), did not impair the thymic lymphoma development (Supplemental Fig. 6). 
Alternatively, we reasoned that the depletion of differentiated leukocytes might promote lymphomagenesis by recruiting into the cell cycle normally quiescent hematopoietic stem/progenitor cells (some of them carrying radiation-induced oncogenic lesions) to replenish the hematopoietic system. To test this hypothesis, following each weekly dose of $\gamma$-irradiation (1.5 Gy), we depleted differentiated leukocytes in the bone marrow and thymus of puma $a^{-1-}$ and puma $^{+/-}$mice by injecting the glucocorticoid dexamethasone, which can induce lymphocyte apoptosis in the absence of Puma (Fig. 4A), albeit slightly less efficiently than in wild-type cells (Villunger et al. 2003). Remarkably, thymic lymphomas then developed in $\sim 30 \%$ of the puma ${ }^{-1-}$ mice within $150 \mathrm{~d}$ (tumor incidence in puma $a^{-f-}$ mice treated with dexamethasone plus $\gamma$-irradiation vs. puma $^{-1-}$ mice treated with $\gamma$-irradiation alone; $P=0.013$ ) (Figs. 3A, 4B). This ability of dexamethasone to promote thymic lymphomagenesis in $\gamma$-irradiated puma $^{+/-}$and puma ${ }^{-/-}$mice is unlikely to be a consequence of impaired immune surveillance, because its administration did not enhance this tumorigenesis in wild-type mice (Fig. 4B). Furthermore, loss of Rag-1- which aborts B- and T-lymphocyte development at an early progenitor stage (Mombaerts et al. 1992), and must therefore free niches in the marrow and thymus-allowed thymic lymphoma development in $\sim 40 \%$ of $\mathrm{puma}^{+/-}$rag$1^{-1-}$ mice within $200 \mathrm{~d}$ (tumor incidence in $\mathrm{puma}^{-/-}$rag$1^{-/-}$mice vs. puma ${ }^{-/-}$mice; $P=0.018$ ) (Fig. 3A), in one

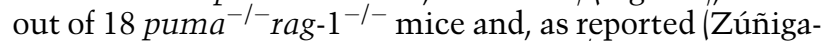
Pflücker et al. 1994), in control rag-1 $1^{-/-}$mice (Supplemental Fig. 7). Although this incidence is lower than that seen in puma ${ }^{-1-}$ treated with both $\gamma$-irradiation and dexamethasone, the tumors had comparable immunophenotypes (data not shown). Interestingly, in contrast to the transgenic mice expressing Bcl-2 in all hematopoietic cells (Fig. 3A), thymic lymphomas develop normally in $\gamma$-irradiated $1 c k-b c l-x_{L}$ transgenic mice (Labi et al. 2010), in which thymocytes but not bone marrow leukocytes are refractory to apoptosis (Grillot et al. 1995). Collectively, these results show that the lymphomagenesis relies not on attrition of thymocytes, but primarily on depletion of bone marrow leukocytes, which stimulates proliferation and tissue repopulation by stem/progenitor cells.
A

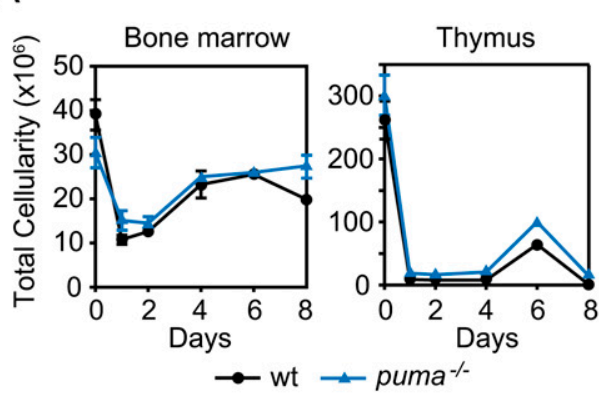

B

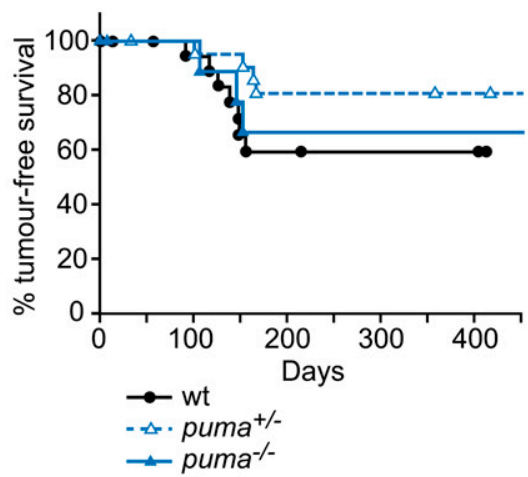

E
C

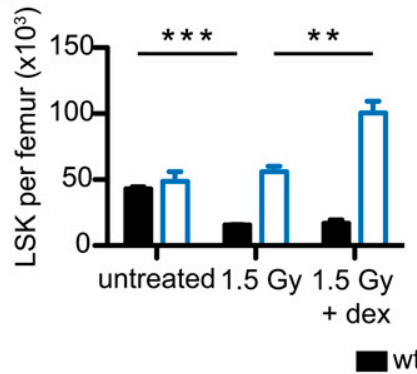

D

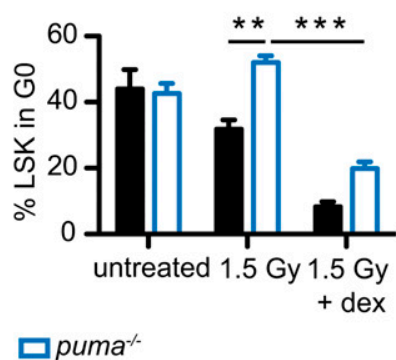

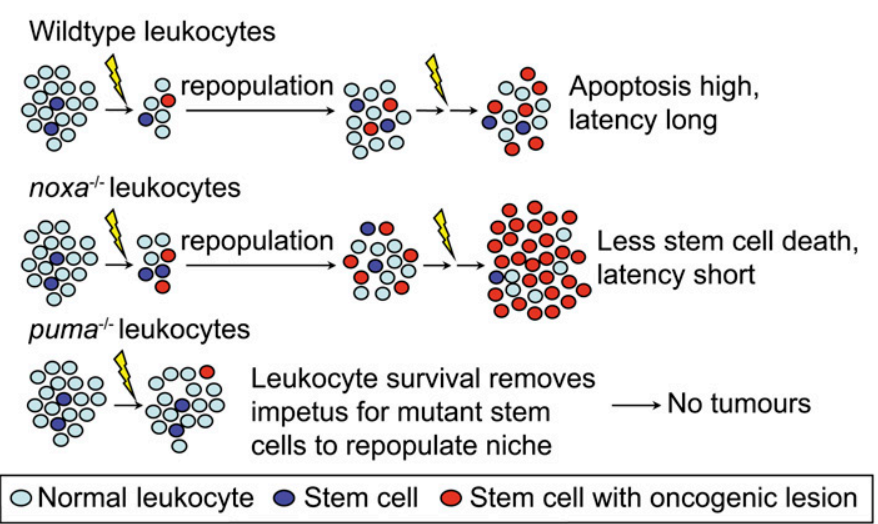

Figure 4. Leukocyte depletion by dexamethasone restores $\gamma$-irradiation-induced thymic lymphoma development in Puma-deficient mice. $(A)$ Total cellularity of the bone marrow and thymus of wild-type and $\mathrm{puma}^{-1-}$ mice after combined treatment with $\gamma$-irradiation (1.5 Gy) plus dexamethasone $(250 \mu \mathrm{g})$ on days 0 and 7 . Mean \pm SEM, $n=2$. (B) Kaplan-Meier curves showing percentage tumor-free survival of mice after four weekly combined treatments with $\gamma$-irradiation $(1.5 \mathrm{~Gy})$ and dexamethasone. For wild-type mice, $n=21$; for puma $a^{+-}$mice, $n=22$; and for puma $^{-/-}$mice, $n=10(P>0.35$ for all comparisons). $(C)$ Impact of combined treatment with $\gamma$-irradiation and dexamethasone on numbers of LSK cells in wild-type and puma ${ }^{-1-}$ mice. LSK cells were analyzed $3 \mathrm{~d}$ following treatment with $\gamma$-irradiation (1.5 Gy) or $\gamma$-irradiation (1.5 Gy) plus dexamethasone $(250 \mu \mathrm{g})$. Mean \pm SEM, $\left.n=4,\left(^{\star \star}\right) P<0.01 ;{ }^{\star \star \star}\right) P<0.001$. $(D)$ Cell cycle status of LSK cells from mice treated as in $C$. Mean \pm SEM, $n=3$. Supplemental Figures 8 and 9 provide FACS data of the cell cycle analysis. $(E)$ Model of thymic lymphoma development in Noxa- and Puma-deficient mice (see the text). We propose that, in wild-type mice, the $\gamma$-irradiation both creates oncogenic lesions within rare cells of the hematopoietic stem/progenitor cell compartment and, by killing most differentiated leukocytes, recruits those cells into the cell cycle to repopulate the compartment. In Noxa-deficient mice, the differentiated leukocytes die normally, but more of the stem/progenitor cells bearing potentially oncogenic mutations survive, thereby hastening tumorigenesis. In Puma-deficient mice, however, the survival of most differentiated cells removes the impetus for recruitment of the mutant stem/progenitor cells that would otherwise found a tumor. 
Combined treatment with $\gamma$-radiation

and dexamethasone but not $\gamma$-radiation

alone promotes cycling of hematopoietic

stem/progenitor in Puma-deficient mice

We therefore compared the responses of the hematopoietic stem/progenitor (LSK) cell compartment in the marrow of wild-type and puma $a^{-/-}$mice to $\gamma$-irradiation. As reported (Shao et al. 2010; Yu et al. 2010), $\gamma$-irradiation depleted the wild-type but not the puma ${ }^{-/-}$LSK cells, and, in the mice that also received dexamethasone, the puma $^{-1-}$ but not the wild-type LSK cells increased significantly (Fig. 4C). Accordingly, cell cycle analysis revealed that the majority of puma ${ }^{-1-}$ LSK cells remained quiescent $3 \mathrm{~d}$ after $\gamma$-irradiation alone, but the concomitant glucocorticoid treatment drove most LSK cells out of $\mathrm{G}_{0}$ (Fig. 4D; Supplemental Figs. 8, 9). Thus, in puma ${ }^{-/-}$ mice, the death of more differentiated leukocytes in the bone marrow induced compensatory proliferation and replenishment by previously quiescent stem/progenitor cells (including some bearing oncogenic lesions), which themselves are resistant to $\gamma$-radiation.

\section{General implications of chronic cellular depletion and repopulation by recruitment and cycling of stem/progenitor cells for tumorigenesis}

Our findings favor the model (Fig. 4E) that, in wild-type mice, Puma-driven bone marrow leukocyte attrition provoked by $\gamma$-irradiation stimulates compensatory proliferation of hematopoietic stem/progenitor cells bearing radiation-induced oncogenic lesions to repopulate the depleted compartment. Subsequent rounds of $\gamma$-irradiation fuel malignant progression by repeated attrition of differentiated leukocytes, mutagenesis, and regeneration by stem/progenitor cells bearing oncogenic lesions that provide a selective advantage (e.g., mutations in p53) (Marusyk et al. 2010). Noxa loss accelerates the lymphomagenesis by promoting survival of the primitive cells bearing potentially oncogenic lesions, but Puma loss ablates it by removing the proliferative impetus provided by the death of the differentiated bone marrow leukocytes.

Some parallels with this novel paradigm may exist in human malignancies. Tumors such as hepatocellular carcinoma in patients suffering from viral- or alcoholisminduced cirrhosis develop from stem or progenitor cells that have been repeatedly called into action through cycles of cell death and regeneration, although some of their proliferative impetus is thought to arise from chronic inflammation (Farazi and DePinho 2006). Furthermore, failure of anti-cancer therapy is often due to repopulation by surviving (resistant) cancer cells (Kim and Tannock 2005), and many cancer survivors later in life develop distinct (second) primary tumors provoked by their courses of radiotherapy or chemotherapy (Allan and Travis 2005).

There is now considerable excitement about the prospect of anti-cancer drugs that act like $\mathrm{BH} 3$-only proteins, such as the promising "BH3 mimetic" ABT-737, which targets only a subset of the prosurvival Bcl-2 family members (Bcl-2, Bcl- $\mathrm{x}_{\mathrm{L}}$, and Bcl-w, but not Mcl-1 or A1) (Oltersdorf et al. 2005; Adams and Cory 2007). Our observation that Puma-mediated death of leukocytes can promote thymic lymphoma development has implications for the design of such agents. It suggests that chronic exposure to a $\mathrm{BH} 3$ mimetic that, like Puma, targets most prosurvival Bcl-2 family members-and would therefore be expected to kill large numbers of differentiated cells (Adams and Cory 2007)—might, in certain circumstances, promote secondary malignancy, particularly in combination with genotoxic anti-cancer therapeutics that can elicit oncogenic lesions in stem/ progenitor cells. Thus, the $\mathrm{BH} 3$ mimetics that target only a subset of the prosurvival family members, or a single member, should be safer than ones targeting most of the family.

\section{Materials and methods}

\section{Thymic lymphoma induction}

Mice (starting at $31 \pm 2 \mathrm{~d}$ of age) were $\gamma$-irradiated weekly for 4 wk with $1.5 \mathrm{~Gy}$ from a ${ }^{60} \mathrm{Co}$ source (Theratron Phoenix, Theratronics). For certain experiments, mice were injected intraperitoneally (i.p.) with dexamethasone sodium phosphate $(250 \mu \mathrm{g}$; DBL) $1 \mathrm{~h}$ after $\gamma$-irradiation. Mice were monitored for $450 \mathrm{~d}$ for signs of illness, and tumor onset was calculated from the last dose of $\gamma$-irradiation. A thymic mass $>50 \mathrm{mg}$ comprised of a T-cell population with an abnormal $\mathrm{CD} 4^{+} / \mathrm{CD}^{+}$FACS profile and/or that was transplantable in recipient mice was considered a thymic lymphoma.

\section{Cell culture, viability, and colony assays}

FACS-sorted ETPs, hematopoietic stem/progenitor cells (LSK) and CLPs were cultured at a starting density of $2 \times 10^{4}$ to $5 \times 10^{4}$ per milliliter at $37^{\circ} \mathrm{C}$ in a humidified $10 \% \mathrm{CO}_{2}$ incubator in complete RPMI medium (RPMI-1640, supplemented with $10 \%$ fetal calf serum, $50 \mu \mathrm{M}$ $\beta$-mercaptoethanol, $100 \mathrm{U} / \mathrm{mL}$ penicillin, $100 \mathrm{mg} / \mathrm{mL}$ streptomycin) with or without $\sim 100 \mathrm{IU} / \mathrm{mL}$ IL-7 and $50 \mathrm{ng} / \mathrm{mL}$ SCF. Cell viability was measured by FACS analysis as the proportion of cells not stained by either Annexin V-FITC or PI (FITC $\left.{ }^{-} \mathrm{PI}^{-}\right)$. The extent of apoptosis induced specifically by $\gamma$-irradiation was calculated as [percent apoptosis - percent spontaneous apoptosis] /[100 - percent spontaneous apoptosis].

Full Materials and Methods and any associated references are available in the Supplemental Material.

\section{Acknowledgments}

We thank Drs. A. Villunger and V. Labi for communicating unpublished results; Drs. S. Cory, S. Akira, D. Metcalf, D.C.S. Huang, P. Bouillet, A.W. Harris, P. Jost, E. Naik, A. Ng, B. Phipson, G. Smyth, and E. Kruse for gifts of mice and reagents, help with experiments, insightful discussions, and comments on the manuscript; K. Vella, K. Pioch, and G. Siciliano for animal care; Dr. F. Battye, C. Tarlinton, V. Milovac, J. Garbe, and C. Young for cell sorting; T. Nikolaou and G. Thomas for $\gamma$-irradiation; J. Corbin for automated blood analysis; B. Helbert and C. Young for genotyping; and Dr. S. Mihajlovic, A. Hasanein, and K. Weston for histological sections. This work was supported by fellowships and grants from the NHMRC (Canberra; program \#257502, CDA 406675 to C.L.S., CDA 461274 to C.J.V., and project \#461214 to L.W.I, the Leukemia and Lymphoma Society (SCOR grant \#7015); the NIH (CA043540), and the JDRF/NHMRC, and a Cancer Council Victoria Post-doctoral Cancer Research Fellowship (to E.M.M.). A.S. and J.M.A. dedicate their contributions to this work to the memory of the late Dr. A.W. Harris.

\section{References}

Adams JM, Cory S. 2007. The Bcl-2 apoptotic switch in cancer development and therapy. Oncogene 26: 1324-1337.

Allan JM, Travis LB. 2005. Mechanisms of therapy-related carcinogenesis. Nat Rev Cancer 5: 943-955.

Clarke AR, Purdie CA, Harrison DJ, Morris RG, Bird CC, Hooper ML, Wyllie AH. 1993. Thymocyte apoptosis induced by p53-dependent and independent pathways. Nature 362: 849-852.

Egle A, Harris AW, Bath ML, O'Reilly L, Cory S. 2004a. VavP-Bcl2 transgenic mice develop follicular lymphoma preceded by germinal center hyperplasia. Blood 103: 2276-2283. 
Egle A, Harris AW, Bouillet P, Cory S. 2004b. Bim is a suppressor of Mycinduced mouse B cell leukemia. Proc Natl Acad Sci 101: 6164-6169.

Erlacher M, Michalak EM, Kelly PN, Labi V, Niederegger H, Coultas L, Adams JM, Strasser A, Villunger A. 2005. BH3-only proteins Puma and Bim are rate-limiting for $\gamma$-radiation and glucocorticoid-induced apoptosis of lymphoid cells in vivo. Blood 106: 4131-4138.

Farazi PA, DePinho RA. 2006. Hepatocellular carcinoma pathogenesis: From genes to environment. Nat Rev Cancer 6: 674-687.

Garrison SP, Jeffers JR, Yang C, Nilsson JA, Hall MA, Rehg JE, Yue W, Yu J, Zhang L, Onciu $M$, et al. 2008. Selection against PUMA gene expression in Myc-driven B-cell lymphomagenesis. Mol Cell Biol 28: 5391-5402.

Grillot DAM, Merino R, Nuñez G. 1995. Bcl- $\mathrm{x}_{\mathrm{L}}$ displays restricted distribution during $\mathrm{T}$ cell development and inhibits multiple forms of apoptosis but not clonal deletion in transgenic mice. J Exp Med 182: 1973-1983.

Hanahan D, Weinberg RA. 2000. The hallmarks of cancer. Cell 100: $57-$ 70.

Hemann MT, Zilfou JT, Zhao Z, Burgess DJ, Hannon GJ, Lowe SW. 2004. Suppression of tumorigenesis by the p53 target PUMA. Proc Natl Acad Sci 101: 9333-9338.

Jeffers JR, Parganas E, Lee Y, Yang C, Wang J, Brennan J, MacLean KH, Han J, Chittenden T, Ihle JN, et al. 2003. Puma is an essential mediator of p53-dependent and -independent apoptotic pathways. Cancer Cell 4: 321-328.

Kaplan HS. 1964. The role of radiation on experimental leukemogenesis. Natl Cancer Inst Monogr 14: 207-220.

Kemp CJ, Wheldon T, Balmain A. 1994. p53-deficient mice are extremely susceptible to radiation-induced tumorigenesis. Nat Genet 8: 66-69.

Kim JI, Tannock IF. 2005. Repopulation of cancer cells during therapy: An important cause of treatment failure. Nat Rev Cancer 5: 516-525.

Labi V, Erlacher M, Krumschnabel G, Manzl C, Tzankov A, Pinon I, Egle A, Villunger A. 2010. Apoptosis of leukocytes triggered by acute DNA damage promotes lymphoma formation.Genes Dev (this issue). doi: 10.1101/gad.1940210.

Lowe SW, Schmitt EM, Smith SW, Osborne BA, Jacks T. 1993. p53 is required for radiation-induced apoptosis in mouse thymocytes. $\mathrm{Na}$ ture 362: 847-849.

Mantovani A, Allavena P, Sica A, Balkwill F. 2008. Cancer-related inflammation. Nature 454: 436-444.

Marusyk A, Porter CC, Zaberezhnyy V, DeGregori J. 2010. Irradiation selects for p53-deficient hematopoietic progenitors. PLoS Biol 8: e1000324. doi: 10.1371/journal.pbio.1000324.

Michalak EM, Villunger A, Adams JM, Strasser A. 2008. In several cell types the tumour suppressor p53 induces apoptosis largely via Puma but Noxa can contribute. Cell Death Differ 15: 1019-1029.

Michalak EM, Jansen ES, Happo L, Cragg MS, Tai L, Smyth GK, Strasser A, Adams JM, Scott CL. 2009. Puma and to a lesser extent Noxa are suppressors of Myc-induced lymphomagenesis. Cell Death Differ 16: 684-696.

Mombaerts P, Iacomini J, Johnson RS, Herrup K, Tonegawa S, Papaioannou VE. 1992. RAG-1-deficient mice have no mature B and T lymphocytes. Cell 68: 869-877.

Nakano K, Vousden KH. 2001. PUMA, a novel proapoptotic gene, is induced by p53. Mol Cell 7: 683-694.

Naugler WE, Sakurai T, Kim S, Maeda S, Kim K, Elsharkawy AM, Karin M. 2007. Gender disparity in liver cancer due to sex differences in MyD88-dependent IL-6 production. Science 317: 121-124.

Oda E, Ohki R, Murasawa H, Nemoto J, Shibue T, Yamashita T, Tokino T, Taniguchi T, Tanaka N. 2000. Noxa, a BH3-only member of the bcl-2 family and candidate mediator of p53-induced apoptosis. Science 288: 1053-1058.

Ogilvy S, Metcalf D, Print CG, Bath ML, Harris AW, Adams JM. 1999. Constitutive bcl-2 expression throughout the hematopoietic compartment affects multiple lineages and enhances progenitor cell survival. Proc Natl Acad Sci 96: 14943-14948.

Oltersdorf T, Elmore SW, Shoemaker AR, Armstrong RC, Augeri DJ, Belli BA, Bruncko M, Deckwerth TL, Dinges J, Hajduk PJ, et al. 2005. An inhibitor of Bcl-2 family proteins induces regression of solid tumours. Nature 435: 677-681.

Rakoff-Nahoum S, Medzhitov R. 2007. Regulation of spontaneous intestinal tumorigenesis through the adaptor protein MyD88. Science 317: 124-127.
Shao L, Sun Y, Zhang Z, Feng W, Gao Y, Cai Z, Wang ZZ, Look AT, Wu WS. 2010. Deletion of proapoptotic Puma selectively protects hematopoietic stem and progenitor cells against high-dose radiation. Blood .115: 4707-4714.

Tagawa H, Karnan S, Suzuki R, Matsuo K, Zhang X, Ota A, Morishima Y, Nakamura S, Seto M. 2005. Genome-wide array-based CGH for mantle cell lymphoma: Identification of homozygous deletions of the proapoptotic gene BIM. Oncogene 24: 1348-1358.

Villunger A, Michalak EM, Coultas L, Müllauer F, Böck G, Ausserlechner MJ, Adams JM, Strasser A. 2003. p53- and drug-induced apoptotic responses mediated by $\mathrm{BH} 3$-only proteins Puma and Noxa. Science 302: $1036-1038$

Vousden KH, Lu X. 2002. Live or let die: The cell's response to p53. Nat Rev Cancer 2: 594-604.

Yu J, Zhang L, Hwang PM, Kinzler KW, Vogelstein B. 2001. PUMA induces the rapid apoptosis of colorectal cancer cells. Mol Cell 7: 673682.

Yu H, Shen H, Yuan Y, Xufeng R, Hu X, Garrison SP, Zhang L, Yu J, Zambetti G, Cheng T. 2010. Deletion of Puma protects hematopoietic stem cells and confers long-term survival in response to high-dose $\gamma$-irradiation. Blood. 115: 3472-3480.

Zúñiga-Pflücker JC, Jiang D, Schwartzberg PL, Lenardo MJ. 1994. Sublethal $\gamma$-radiation induces differentiation of $\mathrm{CD}^{-} / \mathrm{CD}^{-}$into $\mathrm{CD}^{+} / \mathrm{CD} 8^{+}$thymocytes without $\mathrm{T}$ cell receptor $\beta$ rearrangement in recombinase activation gene $2^{-/-}$mice. J Exp Med 180: 1517-1521. 


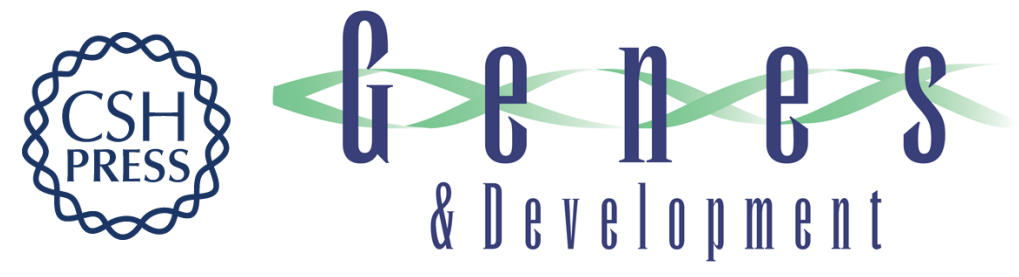

\section{Apoptosis-promoted tumorigenesis: $\gamma$-irradiation-induced thymic lymphomagenesis requires Puma-driven leukocyte death}

Ewa M. Michalak, Cassandra J. Vandenberg, Alex R.D. Delbridge, et al.

Genes Dev. 2010, 24:

Access the most recent version at doi:10.1101/gad.1940110

\section{Supplemental http://genesdev.cshlp.org/content/suppl/2010/07/26/24.15.1608.DC1 \\ Material}

Related Content

Apoptosis of leukocytes triggered by acute DNA damage promotes lymphoma formation

Verena Labi, Miriam Erlacher, Gerhard Krumschnabel, et al.

Genes Dev. August , 2010 24: 1602-1607

References This article cites 34 articles, 14 of which can be accessed free at: http://genesdev.cshlp.org/content/24/15/1608.full.html\#ref-list-1

Articles cited in:

http://genesdev.cshlp.org/content/24/15/1608.full.html\#related-urls

\section{License}

Email Alerting

Service

Receive free email alerts when new articles cite this article - sign up in the box at the top

right corner of the article or click here.

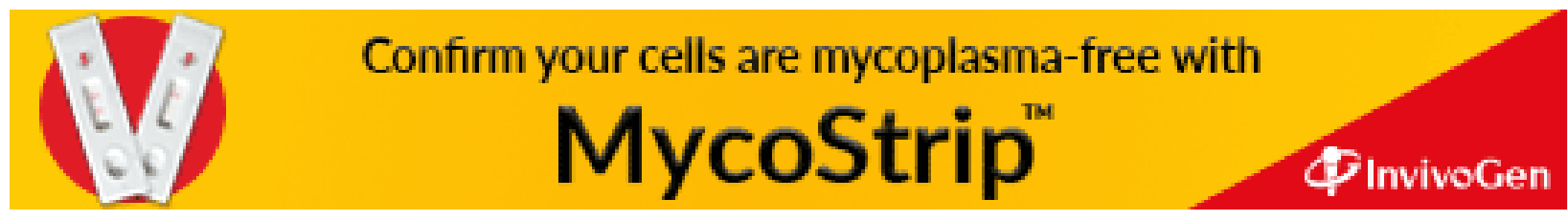

